DOI: $10.53477 / 2668-2001-21-43$

\title{
WILL E-LEARNING HAVE A NEGATIVE INFLUENCE ON UNIVERSITY DROPOUT IN ROMANIA?
}

\author{
Eugen Lungu ${ }^{1}$ \\ Titu Maiorescu University
}

\begin{abstract}
University dropout provides nowadays a very broad theoretical perspective on the understanding of this concept in various higher education systems worldwide. This diversity of theoretical approaches, given the lack of a generally accepted formula for determining university dropout, renders this phenomenon increasingly studied today in the context in which the vast majority of the countries of the world are seeking solutions to reduce it. In this study, we shall discuss a number of theoretical considerations concerning the phenomenon of university dropout and from this perspective we shall try to articulate a viewpoint on the possible effects of online education on this phenomenon in Romania.
\end{abstract}

Keywords: university dropout; online education; higher education; virtual university campus.

\section{INTRODUCTION}

The huge technological progress that the planet has witnessed in recent decades and the need for further development, increasingly promoted by the countries of today's world, so as to raise the level of civilisation and modernise human societies, require a vigorous development of higher education. Thus, higher education is considered vital for the promotion of employment opportunities, social justice and economic progress in each country, being an area of strategic importance on which the future projection of human society as a whole depends.

By analysing a series of articles and theoretical studies that have addressed the issue of "university dropout" in the first decades of this century, we can understand that this concept is a controversial one, because it does not have a high degree of precision in terms of content, which makes it difficult for the States to approach the concrete problems associated with this type of dropout in a different way. But further confusion is caused by the multitude of the terminology used in various countries, but mainly by the way in which it is understood in each country according to the specific regulations of higher education.

Numerous studies have emerged in recent decades in various countries all over the world defining university dropout thereby offering researchers a very broad theoretical perspective for understanding this phenomenon that higher education systems around the world are facing today. The following presentation of the theoretical approaches to university dropout in different countries of the world, from the standpoint of the objectives we have in mind in this article, has the role of shedding more light on this concept, with the purpose of identifying the ways and measures by which university dropout can be decreased in the Romanian space.

Starting from some theoretical approaches related to university dropout in different states of the world, which we will present in the first chapter, we also intend to briefly discuss a series of general aspects concerning the phenomenon of university dropout in Romania, as perceived at the level of the institutions of the Romanian education system. Although no articles or studies have been developed in Romania on this subject, we believe that this aspect of university activity should receive the greatest possible attention, being an indicator of the quality of education promoted by each university, but also at the level of the higher education system in Romania. In this context, we are

\footnotetext{
${ }^{1}$ Corresponding author: eugenbuc2004@yahoo.com
} 
attempting, although it is not an easy thing, to provide an answer to the question: will e-Learning have a negative influence on the university dropout in Romania?

\section{BRIEF THEORETICAL APPROACHES OF THE CONCEPT OF UNIVERSITY DROPOUT IN CERTAIN EDUCATIONAL SYSTEMS WORLDWIDE}

The study of the relevant literature in various States of Europe and North America indicates convincingly that the approach to university dropout has different theoretical nuances, that there is no universal definition of this concept, and that this makes it difficult for educational systems in different countries to apply identical normative frameworks and practices to the issue of dropout in higher education. Consequently, it means that comparing different countries in terms of their treatment of university dropouts in public higher education policies is not an easy task. This stems from the diverse nature of the higher education system in the different countries of the world, on the one hand, and the characteristics of the student populations in each State, on the other hand.

In the public policies pertaining to higher education in various States, as well as in the fundamental normative texts governing this field, the problem of dropping out of university is often found together with that of the completion of studies by students, which makes it difficult to clearly define dropping out of school in the university environment. Moreover, considering this aspect, a series of scholarly studies argue that there is no generic and universally accepted definition of dropping out in the university environment, neither in terms of the completion of university studies. In this regard, the research carried out in several European educational systems, in the field of higher education, has highlighted the fact that a student who lapses into the university dropout phenomenon is one who leaves university early and does not complete his or her studies when he/she normally should. At the same time, the analyses on university dropout are related to university completion rates, which express the proportion of students who have completed university studies.

According to a study published more than a decade and a half ago on the university dropout in Spain (Cabrera et al. 2006), the authors note that student dropout ("student desertion") refers to a variety of situations, defined differently, from those that characterise the interruption of studies by students before their completion. Thus, from a theoretical point of view, students who leave a university before completing their studies, according to the Spanish authors, may find themselves in one of the following situations: involuntary termination (due to violation of regulations); withdrawal from the programme of study for another choice of studies in the same institution; withdrawal from the programme of study in order to take courses at another university; withdrawal from a certain university in order to go to another university to complete the programme of study started; withdrawal from university studies for a new training or employment opportunity; suspension of studies with the intention of resuming them in the future; other possibilities.

Bearing in mind that, in general, the statistics provided by Spanish universities usually identify a "case" of dropping out as a student who, from a theoretical point of view, started his/her studies at a university and along the way it a "moment" occurred when he/she no longer continued his/her studies at the respective university, it can be appreciated that this theoretical approach to dropping out is restrictive and does not lead to conclusive statistics on this phenomenon. A more in-depth analysis of the phenomenon of university dropout in Spain allows us to identify situations that cannot be described as early school leaving. Thus, this category may include students who complete their studies in another non-European community or institution (via the SENECA or ERASMUS programmes, etc.), or students who have interrupted their initial academic itinerary, choosing to enrich it with another itinerary in space, a university training, or some work experience, a common practice among young people in various European countries.

The studies conducted to identify the multiple facets of the university dropout phenomenon over the last few decades confirm these assertions, and this often means that university dropout is not measured at its real magnitude. One such study, carried out in 2005 at the University of La Laguna in Spain, showed that, of the total number of students enrolled in university courses during the academic years 1998/99 (bachelor's degree) and 1999/2000 (associate degree), pointed out that $28 \%$ of the 
students dropped out their initial studies and of these, 32.7\% started courses for another specialisation at the same university and $13.2 \%$ started other studies at another university; the remaining $54.1 \%$ dropped out of university for an indefinite period of time.

The initial dropout figures, as shown in the previous example with regard to Spanish higher education, are alarming, but in reality the number of students dropping out of university is much lower. From this example, as is currently the case in many other EU countries, it appears that the percentage of students who initially dropped out only partially reflects this phenomenon, at a certain calendar date and for a certain category/group of students. Eventually, students who have dropped out may resume their university studies, and this makes it difficult to assess the whole dropout universe. Thus, researchers who have studied this phenomenon appreciate that the meaning of each dropout situation may vary according to the elements that define it, depending also on the person who evaluates it.

Expert studies addressing the many aspects of university dropout in the United States, the analysis of the factors that determine it, and the difficulties encountered by those who attempt to assess it as accurately as possible, have concluded that dropping out of university is a process rather than an isolated event. The characteristics of the university environment, the individual personality traits of students, the family environment, but also the economic context in which students live influence their progress in university career. Therefore, it is almost impossible to identify a single cause of this complex process.

The American authoritative literature acknowledges that the concept of dropping out of university is a controversial one. As a result, the measurement of university dropout rates differs from state to state, but also at the federal level. The lack of generally accepted standards in all states makes it difficult to assess universities from this perspective, as well as to compare these institutions. Many studies conducted in the United States admit that the university dropout is a major event in the lives of students, with a number of influences on the lives of those young people who have decided to leave university. It is also widely accepted that today the social significance of dropping out of university has changed significantly, with its perception being very different from that of other historical periods.

Most studies in the United States have found that dropout in higher education is linked to risk factors in four different areas: individual, academic, family and school. A number of specialized studies have shown that high dropout rates have been found in higher education for nonHispanic Black students, students eligible for free/reduced price lunch, and students with disabilities.

In the United States, although it is known that it is necessary to reduce the dropout rate in universities, the solution is not as obvious. Because abandonment is a process of gradual disconnection from school life, researchers conclude that no factor can be blamed for dropping a student who leaves the university. Nevertheless, a wide variety of variables have been found to correlate with university dropout, and identifying students as high risk has become a crucial topic in efforts to reduce the dropout rate. In addition, given the unique characteristics of the United States, with a society characterised by both important rates of immigration and high rates of internal mobility, students travel frequently, changing universities, districts and states.

The analysis of the causes that determine dropout in the US academic environment has led to the identification of certain factors that most authors associate with dropping out of the academia. A significant percentage of underperforming students and less qualified teachers, for example, are associated with greater dropout rates. Many aspects of family life and socio-economic status are also linked to the dropout behaviour.

\section{WILL ONLINE EDUCATION INFLUENCE THE DROPOUT RATE IN ROMANIA?}

The 2018 National Report on Romania conducted by the Services of the European Commission, which has also been submitted to the European Parliament, the Council, the European Central Bank and the Eurogroup, shows that although some progress has been made in the field of lifelong learning and higher education, however, "subsequent to the adoption in 2015 of the Strategy 
aiming at reducing early school leaving and following the progress made the following year, there have been modest efforts to continue its implementation in 2017. This is reflected in the high rates of the early school leaving" (2018 Country Report on Romania, 15). The report states that regrettably Romania still ranks among the EU countries with the highest dropout rates, including a high dropout rate in higher education.

Specialised studies conducted in Romania, as well as the official documents on education drawn up by the public structures responsible for this area of national interest use the concept of school dropout (PTS), a term which is part of the broader theoretical field in which is the term the university dropout. Although, as presented in the first chapter, there are a variety of definitions of the concept of university dropout in various states of the world, in Romania, university dropout is defined as the leaving of university studies by the student before completing a level of study, without the student obtaining a diploma to complete his studies (Raftu 16). If we refer to one of the usual indicators, namely the proportion of the 25-34 age group who have left education and training early (Early Leavers from Education and Training 25-34, ELET 25-34), Romania has had a very unfavourable record over the last two decades, being currently the only EU country to show a strongly negative trend. Thus, according to the official information, the value of this indicator increased from $12 \%$ in 1997 to $24 \%$ in 2010 and 2011 , followed by a slight decrease to $22 \%$ in 2013 . Also, in 2015 , Romania has an early school leaving rate for $18-24$ year olds of $19.1 \%$, i.e. the third highest-ranking rate in the EU after Spain and Malta. Moreover, in 2017, the dropout rate was of 18.1\% among 18-24 year olds, still one of the highest-ranging in Europe. Given that the EU average rate in 2017 was of $10.6 \%$, Romania's commitment for 2020 of a dropout rate of $11.3 \%$ was a courageous target set by the Romanian authorities in the field of education (European Commission 2018, 240), but the information available so far seems to lead to the conclusion that this target has not yet been reached.

Important official documents drawn up at the level of the Ministry of Education, but also elaborated by some Romanian universities, which are accessible on the Internet, contain a series of aspects which clarify the concept of university dropout and the risk of dropping out, terms generally used in higher education in Romania. Thus, an in-depth analytical study issued by the Centre for Vocational Counselling and Guidance of the University "Ovidius" from Constanța, which also addresses the issue of university dropout, indicates that dropout is determined by the satisfaction of unrealistic reasons and expectations, as well as by their lack of clarity/specificity, emotional preparation and low academic skills, the shock of adaptation and marginalisation from the academic process (Raftu, 16). The same study also points out that the factors that determine university dropout can be both institutional (formal stipulations in the regulations concerning the minimum number of credits to be accumulated, number of absences from university courses, etc.), of a contextual nature (financial difficulties, changes in the family structure, moving to another location, employment - new study needs, etc.), or of an academic nature (lack of motivation, inability to meet requirements, change of priorities, inappropriate choices, dissatisfaction with the academic experience, inability to manage time and workload, etc.) (Raftu 12).

According to the Education Infrastructure Modernisation Strategy (2018-2023), the risk of university dropout is an indicator that measures the percentage of students enrolled in first-year undergraduate programmes with a bachelor's degree average of less than 7 for each university. It is also specified that this indicator can only be applied to universities and according to the criteria set out above, higher priority will be given to those universities with a high risk of dropping out, i.e. a high percentage of students enrolled in first year programmes with low performance (The Government of Romania 64).

The transition to e-learning also in the university environment in Romania, in the context of the COVID 19 pandemic, represents one of the most unprecedented and unexpected events in Romanian higher education in recent decades. Given the fact that there was no experience of university professors in this respect, and that students had no competence in the field of online education, the current preliminary data circulating in various studies and articles on the effectiveness of this formula are not among the most optimistic. 
The results recorded by various Romanian higher education institutions in the context of elearning, considered by specialists to be generally lower than those obtained before the COVID 19 pandemic, were determined by other aspects which demonstrate that the Romanian higher education system was ill-prepared to move to e-learning such as: not all universities made available platforms to provide each teacher and student with an account for online courses; many teachers were not familiar with using computer platforms to deliver online courses; some teachers and students mentioned the lack of adequate equipment (laptops, tablets), which created difficulties in the conduct of courses; Internet connectivity, especially in rural areas of Romania, is a major issue within the Romanian space (Romania ranks $22^{\text {nd }}$ out of 27 as regards Internet connectivity) (DESI 2019).

Taking into account the fact that university dropout has long-term negative effects on social development and economic growth, but also the fact that Romania currently has a high dropout rate, we believe that the Romanian authorities responsible for higher education need to develop strategies and effective policies so that online education does not amplify the phenomenon of university dropout. We believe that, in the future, university education in Romania will integrate the form of e-learning much better, and under these conditions, the responsible factors, both in public higher education and in the private sector, have to find solutions so that the many shortcomings observed so far should be removed as soon as possible.

\section{CONCLUSIONS}

Considering that one of the causes of dropping out of university is the poor adaptation of the student to the learning activity specific to the university environment (the university lays more emphasis on the individual effort of the students; the high difficulty of some subjects in the curriculum compared to those studied in high school; extensive bibliographies for many courses included in the curriculum, etc.), an aspect that is maintained in the context of online courses, we consider that this aspect will exert the same degree of influence on the phenomenon of dropping out of university. However, apart from this cause which contributes to the creation of the phenomenon known as university dropout, there are other causes which are relevant in the context of online education, aspects whose dynamics may intensify the phenomenon of university dropout both at the level of higher education institutions and at national level.

One of the reasons for dropping out of university is linked to the socio-economic situation of the families from which students at risk of dropping out of university originate. Romania is one of the EU countries with a poverty rate that places it at the tail end of the Union, a phenomenon that also affects young people from poor families who have chosen to become university students.

The economic data provided by the European Commission on this year's economic forecasts for Romania indicate that while in 2021 there will be a 3.8\% increase in GDP, a number of Romanian experts in economics believe that the consequences of the crisis generated by the COVID 19 pandemic will be strongly felt especially in the second half of 2021 and will produce negative effects in several sectors of the Romanian economy. Under these circumstances, being affected financially also the families with young people who have the quality of students, the number of students who will drop out of university will undoubtedly increase. Also, the lack or scarcity of financial resources makes it difficult not only to pay the tuition fees (in the case of the students who are on the annual fee), but also to purchase a computer by the students who have this need, in order to be able to participate in online courses, aspects which, therefore, will certainly lead some young people to decide to drop out of higher education.

The lack of the direct contact of the student with university life, as is the case in traditional education, will, in our opinion, amplify the phenomenon of university dropout in the context of elearning. The virtual university campus, the place where online courses take place, cannot have the magic of a "real amphitheatre" where students enter the traditional paradigm of university education and will never be able to create those strong informal links between students and between students and professors, relationships that confer a lot of charm to student life. Online education, without being considered as an inefficient educational field, is a great challenge for the Romanian education system at all levels, as well as a new start, yet we believe that from the point of view of university dropout, it 
will not contribute to lowering the percentage of early school leavers. But, over time, the improvement of the teachers in this direction, alongside the gradual reduction of the negative effects that other factors have on university dropouts, may allow us to look with optimism at the way e-learning in Romania will develop towards the year 2030.

\section{REFERENCES}

Cabrera, Lidia, José Tomas Bethencourt, Pedro Alvarez, Alfonso Pérez, and Miriam González. 2006. "The Problem of University Dropout", Revista ELectrónica de Investigación y EValuación Educativa, RELIEVE, v. 12, n. 2. 171-203.

European Commission. 2018. Commission staff working document, Education and Training Monitor 2018. Accessed January 20, 2021. https://ec.europa.eu/transparency/regdoc/rep/10102/2018/ en/swd-2018-435-f1-en-main-part-3.pdf

DESI (Digital Economy and Society Index) 2019. Accessed January 27, 2021. https://ec.europa.eu/digital-single-market/en/news/digital-economy-and-society-index-desi-2019

European Commission. 2021. Previziunile economice din iarna anului 2021: România - PIB-ul va crește cu 3,8\% în 2021, respectiv cu 4\% în 2022, Accessed February 25, 2021. https://ec.europa.eu/romania/news/20210211_previziuni_economice_iarna_ro

Raftu, Gheorghe. 2019. "Identificarea cauzelor care influențează fenomenul de dezinserție academică la studenții din cadrul Universității «Ovidius» din Constanța", Studiu al Universității "Ovidius" din Constanța, Accessed January 27, 2021. http://consiliere.univ-ovidius.ro/wp-content/uploads/ 2019/11/Studiu-dezinsertie-academica_2018_UOC.pdf

The Government of Romania. 2018. Strategia pentru modernizarea infrastructurii educaționale 20182023. Accessed February 11, 2021. https://www.edu.ro/sites/default/files/Strategie\%20SMIE\% 2023.04.2018.pdf

2018 Country Report on Romania (Study Document of the Services of the Commission), Communique of the Commission to the European Parliament, the Council, the European Central Bank and the Eurogroup. 2018. Accessed February 16, 2021. https://ec.europa.eu/info/sites/info/files/2018-european-semester-country-report-romania-ro.pdf 